\title{
The (reformed) Dublin III Regulation-a tool for enhanced effectiveness and higher standards of protection?
}

\section{Constantin Hruschka}

Published online: 12 February 2015

(C) ERA 2015

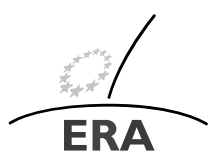

EUROPÄISCHE RECHTSAKADEMIE ACADEMY OF EUROPEAN LAW ACADEMIE DE DROIT EUROPEEN ACCADEMIA DI DIRITTO EUROPEO TRIER - TREVES - TREVIRI

\begin{abstract}
The aim of the (recast) Dublin III Regulation is to enhance the effectiveness of the Dublin system while securing higher standards of protection for applicants. The Regulation provides for new tools to achieve these aims. In practice, the implementation of the new Regulation has proven to be challenging, but is generally working well. However, there are still areas for improvement. Especially the right to family life and the right to an effective remedy, need to be further strengthened to conform to human rights standards.
\end{abstract}

Keywords International protection · Dublin III Regulation · Fundamental rights

\section{Introduction}

Following the evaluation of the Dublin system in $2007^{1}$ the Commission tabled a proposal for a recast of the so-called Dublin II Regulation ${ }^{2}$ in $2008 .^{3}$ The initial proposal immediately faced strong opposition from the Member States for various

\footnotetext{
${ }^{1}$ Report from the Commission to the European Parliament and the Council on the evaluation of the Dublin system, COM(2007) 299 final, 6 June 2007.

${ }^{2}$ Council Regulation (EC) No 343/2003 of 18 February 2003 establishing the criteria and mechanisms for determining the Member State responsible for examining an asylum application lodged in one of the Member States by a third-country national, OJ, L 50 of 25 February 2003, 1 ("Dublin II Regulation").

${ }^{3} \operatorname{COM}(2008) 820$ final, 3 December 2008.
}

The article is based on a presentation given at the ERA conference "Applying the Reformed Dublin Regulation" which took place on 28-29 April 2014 in Trier.

C. Hruschka, Dr., Lecturer $(\varangle)$

University of Bielefeld, Hallerstr. 50, 3012 Bern, Switzerland

e-mail: constantin.hruschka@osar.ch 
reasons. After several rounds of consultations the new substantially revised Regulation (EU) No. 604/2013 of the European Parliament and of the Council ${ }^{4}$ entered into force in July $2013 .{ }^{5}$ Following the logical numbering it is now commonly referred to as "Dublin III Regulation." The main aim of the recast was to enhance effectiveness in the application of the Dublin system and to ensure higher standards of protection for persons subjected to the Dublin procedure. ${ }^{6}$

Many of the inconsistencies and potential areas for improvement in the application of the Dublin II Regulation had been also highlighted by scholars ${ }^{7}$ and in non-governmental reports looking at the application of the Dublin II Regulation. ${ }^{8}$ Similarly, the case law of national courts as well as the European Court of Human Rights (ECtHR) indicated a need to review the Dublin II Regulation. The necessary adjustments were so significant that a recast was deemed necessary. ${ }^{9}$ Moreover, the existing case law of the Court of Justice of the European Union ('CJEU') has helped to clarify some of the most fundamental legal issues and has significantly influenced the recast process.

The case law covered a number of important themes starting with the time limits for transfers in the case of appeals. ${ }^{10}$ Prior to the recast the CJEU had also issued judgments on the principle of non-refoulement and on the use of the sovereignty clause ${ }^{11}$ on the application of the Dublin system in the case of withdrawal of the asylum application, ${ }^{12}$ on the application of the Reception Conditions Directive ${ }^{13}$ during Dublin procedures ${ }^{14}$ on the application of the "dependency clause" of Article 15 (2) of the Dublin-II-Regulation, ${ }^{15}$ on the obligation to investigate in cases of envisaged transfers, ${ }^{16}$ and on the application of Article 6 (2) of the Dublin-II-Regulation (concerning unaccompanied minors with no family members (or relatives) in the Dublin area) and the best interests of the child. ${ }^{17}$ These judgments have informed and influ-

\footnotetext{
${ }^{4}$ Regulation (EU) No 604/2013 of the European Parliament and of the Council of 26 June 2013 establishing the criteria and mechanisms for determining the Member State responsible for examining an application for international protection lodged in one of the Member States by a third-country national or a stateless person (recast), OJ, L 180 of 29 June 2013, 31 (“Dublin III Regulation”).

${ }^{5}$ See the documents of the recast process as available under Eur-Lex, in particular the first proposal by the Commission of 2008 (see above note 3).

${ }^{6}$ See e.g. recital 9 of the Dublin III Regulation.

${ }^{7}$ See e.g. Maiani/Vevstad [2].

${ }^{8}$ See e.g. UNHCR and ECRE [3].

${ }^{9}$ See recital 1 of the Dublin III Regulation.

${ }^{10}$ CJEU, Case C-19/08, Petrosian, 29 January 2009, ECLI:EU:C:2009:41.

${ }^{11}$ CJEU, Case C-411/10 and C-493/10, N.S. and Others, 21 December 2011, ECLI:EU:C:2011:865. The outcome of this judgment was reconfirmed by the CJEU after the recast process had ended in the judgement, Case C-4/11, Puid, 14 November 2013, ECLI:EU:C:2013:740.

${ }^{12}$ CJEU, Case C-620/10, Kastrati, 3 May 2012, ECLI:EU:C:2012:265.

${ }^{13}$ Council Directive 2003/9/EC of 27 January 2003 laying down minimum standards for the reception of asylum seekers, OJ L 31 of 6 February 2003, 18.

${ }^{14}$ CJEU, Case C-179/11, CIMADE and GISTI, 27 September 2012, ECLI:EU:C:2012:594.

${ }^{15}$ CJEU, Case C-245/11, K, 6 November 2012, ECLI:EU:C:2012:685.

${ }^{16}$ CJEU, Case C-528/11, Halaf, 30 May 2013, ECLI:EU:C:2013:342.

${ }^{17}$ CJEU, Case C-648/11, MA and Others, 6 June 2013, ECLI:EU:C:2013:367.
} 
enced the recast process. Since the end of the recast process, the CJEU has given two rulings: one on the (non-)obligation of Member States to use the sovereignty clause ${ }^{18}$ and one on individual rights and appeals in the context of the criterion of illegal entry (Article 10 (1) of the Dublin-II-Regulation). ${ }^{19}$

The purpose of the recast was to further develop and improve the Dublin system. Consequently, the underlying principles of the Dublin system were re-confirmed in the light of the evaluation and practical experience with the system. The main aims of the recast were to improve "the effectiveness of the Dublin system and the protection granted to applicants under that system." ${ }^{20}$ One key factor of the prolonged negotiations was article 31 of the Commission Proposal of 2008 providing for a possibility to suspend transfers to Member States under certain circumstances. This idea faced strong opposition from some Member States. As a compromise Article $33^{21}$ provides for "a mechanism for early warning, preparedness and crisis management." The exact shape and functioning of the mechanism as well as its potential is still unclear. At the time of writing, EASO had started steps to find a way to implement this mechanism. The power and effectiveness of this mechanism will very much depend on its practical application within the CEAS and by EASO.

On a practical note the aim to enhance effectiveness is reflected by the introduction of Regulation No. 118/2014 22 amending the 2003 Dublin Implementing Regulation. $^{23}$

Another aspect in this context is the content of the recast EURODAC Regulation. It is further noteworthy that Denmark does not take part in the application of the recast Regulation according to recital 42 , although in practice Denmark is fully participating in the system. ${ }^{24}$

This article will analyze the "reformed" Dublin system as established by the recast under the two main themes of enhanced effectiveness and higher standards of protection. In the concluding remarks it will highlight some areas for improvement and clarification, and will propose some ways for a human-rights sensitive way forward for the application of the Dublin III Regulation.

\footnotetext{
${ }^{18}$ See above note 11.

${ }^{19}$ CJEU, Case C-394/12, Abdullahi, 10 December 2013, ECLI:EU:C:2013:813.

${ }^{20}$ Recital 9 of the Dublin III Regulation.

${ }^{21}$ All articles with no specification are articles of the Dublin III Regulation.

${ }^{22}$ Commission Implementing Regulation (EU) No 118/2014 of 30 January 2014 amending Regulation (EC) No 1560/2003 laying down detailed rules for the application of Council Regulation (EC) No 343/2003 establishing the criteria and mechanisms for determining the Member State responsible for examining an asylum application lodged in one of the Member States by a third-country national, OJ L 39 of 8 February 2014, 4.

${ }^{23}$ Commission Regulation (EC) No 1560/2003 of 2 September 2003 laying down detailed rules for the application of Council Regulation (EC) No 343/2003 establishing the criteria and mechanisms for determining the Member State responsible for examining an asylum application lodged in one of the Member States by a third-country national, OJ L 222 of 5 September 2003, 3.

${ }^{24}$ As the Dublin II Regulation was repealed (see article 48) there is no legal basis in place for the application of the Dublin rules in procedures with Denmark.
} 


\section{Enhancing effectiveness}

\subsection{International protection}

As the Dublin II Regulation was the first legal act of the CEAS that entered into force its compatibility with the rest of the EU asylum acquis was not fully guaranteed. Therefore, one major objective of the recast was to align the Dublin system with the system of the CEAS by incorporating the concept of "international protection"comprising refugee protection and subsidiary protection-into the Dublin III Regulation. The scope of application for Dublin procedures has been considerably widened by this principal change. ${ }^{25}$ Consequently, the Dublin system now applies to all applicants for international protection and not only to persons asking for refugee protection. Also the family criteria have been changed accordingly. According to Article 9 of the Dublin III Regulation a person, who has been granted international protection, may be joined by a family member, if the family member has applied for international protection in the Dublin area. A similar (but practically less significant) change has been made in Article 10 of the Dublin III Regulation for persons whose application is still being determined at first instance. Looking at the aim to create a real CEAS these changes are logical and have been inevitable from an EU law perspective. In practice, these changes may pose certain challenges. One of them is the fact that the associated states Switzerland and Liechtenstein do not apply the concept of subsidiary protection in their national law and the respective complementary form of protection ("provisional admission") is — in both countries - associated with a "non-status" that does not guarantee the same rights as provided to beneficiaries of subsidiary protection under the Qualification Directive.

From a practitioner's point of view the incorporation of the concept of international protection means that it has become more difficult to "circumvent" the Dublin system by not applying for refugee protection. After the recast it would be necessary to refrain from lodging an application for international protection and to rely instead on national humanitarian protection and/or non-refoulement provisions if a client does not want to return to the potentially responsible state. Looking at the consequences this may also mean that persons are still able to avoid transfers under the Dublin system, but that they are facing as a consequence a potentially precarious status in the country where they are staying. ${ }^{26}$ From a purely legal perspective, this might not be seen as a problem as the persons are "circumventing" the system. Looking at it from the perspective of the asylum seeker/lawyer the consequences are far more severe as it may affect the ability to integrate into society and build a livelihood for potential refugees.

\subsection{Criteria}

Regarding the criteria, the main principles for the determination of responsibility remain the same. If the asylum seeker is not an unaccompanied minor (Article 8) or

\footnotetext{
${ }^{25}$ See Recital 10.

${ }^{26}$ This is only possible if a system of protection on the national level allows for such an application. For the case of Germany, this effect has been described by Bender/Bethke, [1], 358.
} 
does not have family members in another Dublin State, (Articles 9-11) the state that has facilitated the entry of the third-country national or stateless person to the territory of the Member States is responsible for examining the asylum application. The same logical sequence as set out in the Dublin-II-Regulation of residence permits, visa, non-denial of illegal entry, visa waived entry and asylum application in a transit zone of an international airport has been retained (Articles 12-15). For reasons of clarity the "first application reason" (Article 13 of the Dublin II Regulation) has been moved to Article 3 (2) 1.

Article 3 (2) and (3) contains the reflection of N.S. and Others: ${ }^{27}$ If a transfer cannot be carried out due to "systemic flaws in the asylum procedure and in the reception conditions for applicants in that Member State, resulting in a risk of inhuman or degrading treatment within the meaning of Article 4 of the Charter of Fundamental Rights of the European Union," the assessment of the criteria continues. This means that the Member State that carries out the Dublin procedure restarts the assessment with the next criterion. ${ }^{28}$ If no responsible Member State can be established through the criteria and no asylum application was lodged in a Member State to which the person could be transferred, the Member State carrying out the Dublin assessment is responsible for the substantive examination of the asylum application. This new set of rules in conjunction with Article $18(2)^{29}$ aims at guaranteeing that every asylum seeker has access to a substantive examination of his/her claim in the EU. ${ }^{30}$ The new level of details within the family criteria is also remarkable and will be further examined in conjunction with the dependency and discretionary clause under 3.1.2 below.

\subsection{Requests and time limits}

Time limits within the Dublin III Regulation have been significantly amended as the framework now also provides for time limits for take back requests (Articles 23 and 24) and not only as in the previous Regulation for take charge requests. In practice, this will lead to a maximum length of a Dublin procedure of 11 months (if no appeal is lodged) and will therefore facilitate the efficient use of the Dublin system from this point of view. The regular time limits are three months for take charge requests and for take back requests; if the request is based on Eurodac data the time limit for making the request shall be "within two months of receiving of the Eurodac hit" (Articles 21, 23 and 24). This seems to be complicated as there are now two starting

\footnotetext{
${ }^{27}$ See above note 11.

${ }^{28}$ E.g. if Greece was determined to be responsible according to the illegal entry clause (article 13 (1)) and a transfer to Greece cannot be carried out. The Member State needs to examine the criteria starting with the illegal stay clause (article 13 (2)).

${ }^{29}$ Article 18 (2) foresees that the responsible Member State shall "examine or complete the examination of the application for international protection made by the applicant" also in cases where the applicant has left the territory prior to the finalization of the examination. This provision has the effect that a discontinuation for formal reasons of an examination (e.g. because of "implicit withdrawal" or "renunciation" by the applicant) is no longer compatible with the rules of the CEAS.

${ }^{30}$ The only exception foreseen is the (practically so far quasi irrelevant) safe third country clause of article $3(3)$.
} 
points for the time limits: if Eurodac data is available the reception of the data by the Member State is determinative, whereas in cases without such data the starting point is the asylum application. If a Member State does not request the taking over of the asylum procedure within the time limits, it will be responsible for examining the asylum application (if no asylum application was lodged in the requesting state, the state of stay shall give the person a possibility to lodge an asylum application if he/she is staying without residence documents in that Member State (Article 24 (3)).

The already existing time limits for replying to such requests have been slightly modified and to some extent clarified. The Regulation further clarifies that there are no time limits for humanitarian requests before a first instance decision on the substance is taken. The reason for this is that the respective circumstances may arise after the time limits have passed. In case a humanitarian request is lodged to another Member State the reply by this Member State shall be given within two months (Article 17 (2)). The responsibility does not shift to the requested state if no answer is provided.

If a state lodges a Dublin request to another state via DublinNet it is required to send the respective means of proof and/or circumstantial evidence with the request. ${ }^{31}$ Any negative answer shall state the reasons for the refusal. If one Member State refuses a take back or take charge request, it shall give reasons for the refusal. The requesting state may ask the other State for information (Article 34 of the Dublin III Regulation and Annex V of the Regulation 118/2014), but there are no time limits for this procedure so that consensus needs to be reached between the two States that are involved. This need for consensus (with no formal "appeals" procedure) and the fact that most of the States insist on formal means of proof for accepting responsibility has been already highlighted by the Commission in the evaluation report. ${ }^{32}$ The new provisions do not effectively address these issues and the reformed Dublin III system still needs to establish "rules of procedure" regarding the newly introduced elements.

\subsection{Transfers and information sharing}

Section VI (on transfers) consisting of Articles 29-32 brings together the provisions on transfers and clarifies some of the key questions that had arisen in the application of the Dublin II Regulation. Article 29 contains the ground rules on the modalities and time limits for transfers. Whereas the time limits for transfers remain unchanged, ${ }^{33}$ some of the modalities have been changed and/or more clearly defined. The principle that the transfer should be carried out in a "humane manner and with full respect for fundamental rights and human dignity" has been inserted into the Regulation for supervised departures or transfers under escort (Article 29 (1) 2). The costs of transfers

\footnotetext{
${ }^{31}$ See articles 21 (3), 23 (4) and 24 (5) refer to the respective lists in article 22 (3).

${ }^{32}$ See evaluation report (note 1$), 8$.

${ }^{33}$ According to Article 29 (1) and (2) the transfer needs to be carried out within a time limit of six months of the acceptance of the request. In accordance with the CJEU decision in the case Petrosian the time limits starts to run from the final decision on an appeal or review where there is suspensive effect in accordance with article 27 (3). within six months from the final decisions. The time limit may be extended if the person is in criminal detention (up to maximum of one year) or if the person absconds (up to a maximum period of 18 months). If the transfer is not carried out within this time limit responsibility is transferred to the requesting state.
} 
are regulated in article 30 and are normally on the transferring state. This rule also applies to erroneous transfers or transfers that have been carried out if the transfer decision is subsequently overturned on appeal or review. Article 30 (3) explicitly states that transferees shall not be required to meet the transfer costs.

Articles 31 and 32 provide for the exchange of relevant information and health data before a transfer is carried out. This exchange is facilitated and regulated in more depth by the new set of rules and the forms provided for the exchange of data. There are separate forms for the information exchange for "normal" cases, in dependency cases, in cases concerning unaccompanied and for the exchange of health data (Annexes VI-IX of Regulation 118/2014).

\subsection{Eurodac}

The recast Eurodac Regulation that will enter into force on 21 July 2015 contains (from a Dublin point of view) only a small number changes. The principles and the situations in which a comparison of Eurodac data for the purpose of the allocation of responsibility is carried out remain the same. The recast mainly envisaged that Eurodac data may also be used under clearly defined circumstances by law enforcement authorities and Europol for law enforcement purpose and that the Regulation would be compatible with the Regulation (EU) No 1077/2011 establishing a European Agency for the operational management of large-scale IT systems in the area of freedom, security and justice. Consequently, the rules for the collection, transmission and comparison of data for Dublin purposes remained basically the same, but the changes had effects on the numbering of the respective articles. Under the preconditions that the respective person is over 14 years of age, data in Eurodac is still stored in two situations: (1) if a person lodges an asylum application data is entered and stored for 10 years (article 9-12 of the recast Eurodac Regulation), (2) if a thirdcountry national or a stateless person is apprehended in connection with the irregular crossing of an external border. This latter data may be stored in the database for 18 months (Articles 14-16 of the recast Eurodac Regulation). Data of third-country nationals or stateless persons "found illegally staying" in the territory of a Member State is still not stored in Eurodac, but may be used on a one time basis for the purpose of comparison in (potential) Dublin procedures (article 17 of the recast Eurodac Regulation).

Moreover, the recast Regulation addresses some practical challenges of diverging nature such as specification of time limits and data to be collected (articles 9 and 14 of the recast Eurodac regulation) and the rules for data use if a person is granted international protection, a residence permit or citizenship (articles 13, 16 and 18 of the recast Eurodac Regulation). Moreover, the rules for data protection have been fully revised and contain more safeguards for the respective persons.

\section{Ensuring higher standards of protection for applicants}

The second part of the two-fold aim of the recast was to ensure higher standards of protection for applicants. The following analysis of these standards is divided into four parts. 


\subsection{Protection of the right to family life}

\subsubsection{Best interests of the child}

The primary consideration of the best interests of the child was-despite its foundation in Article 3 of the Convention of the Rights of the Child and in Article 24 (2) CFR - in practice not always secured as the Dublin II Regulation only contained an explicit reference to this principle for the setting that an unaccompanied minor was to be reunited with his/her family (Article 6 (1) of the Dublin II Regulation). This had led to diverging practice with regard to the protection of minors by the Member States mostly dependent on the strength of the national system for the protection of children. ${ }^{34}$ The new set of rules in article 6 ("guarantees for minors") addresses this issue and provides for a full incorporation of the principle of the best interests of the child into the Dublin system. Article 6 (1) does establish that this principle is to be applied in all Dublin procedures regarding minors. Consequently, it is not limited to unaccompanied minors and Member States have to ensure that the best interests of minors are also considered if the Dublin procedure concerns accompanied minors. Article 6 (3) provides for examples of factors that shall be considered in this regard, most notably, the well-being and the social development of the minor as well as safety and security questions and - as appropriate, depending on age and maturity - the views of the minor. It will remain to be seen whether for the cases of accompanied minors these guarantees will have a practical effect as there are no rules for the implementation of the best interests principle for accompanied minors.

The protection of unaccompanied minors offered by Article 6 and Article 8 in Dublin procedures is a significant improvement over the Dublin II Regulation. Just before the entry into force of the recast regulation, the judgement of the CJEU in the case $M A$ and Others $^{35}$ had practically put an end to transfers of unaccompanied minors within the Dublin system, if no family member or relative was present in the territory of any Member State. ${ }^{36}$ The judgement in essence provides for a pre-disposed test of the best interests of the child and comes to the conclusion that transfers should not be carried out if no family member (or relative) is legally present in the territory of the Member States. Informed by this reading the CJEU interprets Article 6 (2) of the Dublin II Regulation as referring to the most recent application. The Court also

\footnotetext{
${ }^{34}$ In many Member States the crucial question was to what extent youth authorities have an influence in Dublin procedures and/or whether the protection of the right of the child was actually done by immigration specialists of youth protection entities.

${ }^{35}$ See above note 17.

${ }^{36}$ Some Nordic States still aim to transfer unaccompanied minors under a Dublin procedure if the respective minors already had received a negative decision in another Member State. This interpretation of the judgment MA is based on a diverging reading of para. 63 and 64 of the judgment and places the principle that there should only be one substantial decision over the principle that minors should not be transferred at all (the latter is the reading of the Commission according to its proposal as well as of the majority of Member States).
} 
states that Article 6 (2) is in this regard an exception from the principle of Article 5 (2)..$^{37}$

As the judgement came in after the negotiations on the recast had been finished the Commission was invited to consider a revision of Article 8 (4) in the light of this judgement. ${ }^{38}$ The Commission has lodged a proposal for the amendment of Article 8 (4) in June 2014. ${ }^{39}$ The content of the proposal has the potential to further enhance the compatibility of the Dublin system with the framework for the protection of unaccompanied children. ${ }^{40}$ Moreover, the new set of rules for minors and the reference of article 6 to the necessity to assess the best interests of the child in every Dublin procedure might also facilitate the development of a uniform definition of the best interests of the child within the CEAS (and potentially beyond). The legal standards provided for by article 24 (2) CFR will need to be developed and assessed in this process.

\subsubsection{Family unity at large}

Another area of intended improvements was the protection of right to family life. Already recital 14 contains a clearer commitment to its protection than the Dublin II Regulation. It states that "the respect for family life should be a primary consideration of Member States" when applying the Regulation. This reinforcement is also mirrored the new definitions in Article 2 lit. g) and h). Moreover, the adaptation of the Regulation to the concept of international protection has consequences for the criteria that are related to family unity.

Nevertheless, the strengthening of the right to family life might in practice not have the intended effects as the new provisions do not provide for a coherent approach to this protection. For example, in total there are six constellations in which the family unity is dependent of the definition of a family and related pre-conditions. Within this framework five different standards are defined. In practice, this is bound to lead to confusion and will most likely have negative effects on the application of family related criteria. ${ }^{41}$

Another consequence of the recast is that the dependency clause (Article 16) has been upgraded into a quasi criterion, which seems to be a step into the direction of better protection of family members and relatives. Nevertheless, the actual new provision falls short of the scope of application that the CJEU had defined for Article 15

\footnotetext{
${ }^{37}$ Art. 5 (2) provides for the "petrification principle". This means that for the purpose of establishing responsibility the situation at the time of the first asylum application needs to be assessed. This principle is retained in the recast Regulation in article 7 (2).

${ }^{38}$ Statement by the Council, the European Parliament and the Commission, published as part of the recast Regulation, OJ L 180 of 29 June 2013, 59.

${ }^{39}$ Proposal for a Regulation of the European Parliament and of the Council amending Regulation (EU) No 604/2013 as regards determining the Member State responsible for examining the application for international protection of unaccompanied minors with no family member, sibling or relative legally present in a Member State, COM (2014), 382 of 26 June 2014.

${ }^{40}$ See e.g. UN Committee on the Rights of the Child $(C R C)[4,5]$.

${ }^{41}$ For a more in-depth analysis of these effects see Maiani/Hruschka, Der Schutz der Familieneinheit in Dublin-Verfahren, ZAR 2014, 69.
} 
(2) of the Dublin II Regulation in its judgment $K{ }^{42}$ This effect may only be countered by a rights-sensitive approach to article 17 . Article 17 contains the discretionary clauses and consists of a combination of the former sovereignty clause and the general part of the former humanitarian clause. Looking at the drafting history especially Article 17 (2) has been designed to allow for the respect of the right to family life beyond the criteria of the Regulation. Such an approach is all the more warranted as - as described - one aim of the recast was to strengthen the rights of applicants in general and in particular the right to family life. This potential is to some extent already undermined by the case law of the CJEU as it has on several occasions at least alluded to an interpretation of the sovereignty clause that makes the invocation of its application by applicants at least difficult. ${ }^{43}$ The potential of Article 17 in family related cases is nevertheless apparent and authorities should actually use it at least to ensure that the strengthening of the right to family life becomes a reality in practice under Dublin III.

\subsection{Procedural rights in first instance procedures}

With the introduction of Articles 4 and 5 the procedural rights of the applicants have been significantly strengthened. Article 4 gives an explicit reference to the right to information. This right was also stressed by the ECtHR in the context of potential violations of Article 3 in conjunction with Article 13 in "asylum cases." In particular this right has been an important argument in the rulings against Greece and Italy in the cases M.S.S. ${ }^{44}$ and Hirsi. ${ }^{45}$ The information provided to applicants has been regulated by Article 16a of the Dublin Implementing Regulation (as inserted by the Regulation 118/2014) that provides for common information leaflets for applicants. There are separate leaflets for applicants for international protection for unaccompanied minors and for apprehended third-country nationals and stateless persons. These leaflets are set out in Annexes X-XII of Regulation 118/2014. In practice, the leaflets have created some significant technical problems regarding the necessary insertion of the national law. This has led to the fact that currently (September 2014) the leaflets of the Commission are not always used by Member States or have been significantly adapted by MS prior to its use. Also the fact that the Commission has only provided for translations into ten languages has created practical problems. Some Member States have translated the leaflets in more languages at their own initiative. Member States have also stated that they use the common leaflet for unaccompanied minors also for applicants for international protection as it is generally better understood by applicants. ${ }^{46}$

Article 5 provides for a personal interview of persons in a Dublin procedure and aims at securing the right to be heard. As Article 5 does not explicitly state when

\footnotetext{
${ }^{42}$ See above note 15 .

${ }^{43}$ See e.g. the decisions by the CJEU in N.S. and Others, MA and Others as well as in Puid (see above notes 11 and 17).

${ }^{44}$ ECtHR, Application No. 30696/09, M.S.S. v. Belgium and Greece, 21 January 2013.

${ }^{45}$ ECtHR, Application No. 27765/09, Hirsi Jamaa an Others v. Italy, 23 February 2012.

${ }^{46}$ Information obtained from officials of Member States at a meeting in Malta in September 2014.
} 
and how such an interview should be held, the practice of Member States varies quite significantly. Some provide for this interview at the beginning of the procedure and do not specify the country that might be responsible for the asylum application, whereas other Member States do give the applicant the possibility to explicitly speak to the intended decision. An interview would therefore be most logically need to be conducted after the decision was made to lodge a take back or take charge request to another Member State. Looking at the reasoning of the CJEU in the judgement $M . M .^{47}$ it seems to be clear that an applicant needs to be-at least in practice-in the position to bring forward arguments against the actual transfer decision.

\subsection{Effective legal remedy}

The recast Regulation newly contains rules for appeals that have been previously referred to the national context. The main reasons for this approach seem to be twofold. The first reason is the development of better legal standards. Since the entry into force of the Charter of Fundamental Rights of the European Union its Article 47 is mandatorily providing for an effective legal remedy and also the case law of the ECtHR has significantly developed since the adoption of the Dublin II Regulation. ${ }^{48}$ The second reason seems to be the diverging practice of Member States regarding appeals against Dublin decisions. The new rules consist of two principal safeguards. Article 26 provides for a mandatory notification of the Dublin decision including the necessary information on legal remedies and the possibility to apply for suspensive effect. Article 27 provides for three different models of possible appeals procedures. The choice of providing models in a binding Regulation seems to be inconsistent with the aim to establish common standards, but on a practical level these models represent the different legal traditions regarding appeals in the Member States. They are all oriented on the fundamental principle of an effective remedy in law and practice. Recital 19 explains that Member States are required to assess the law and practice in the requested state at least at the level of appeal. ${ }^{49}$ These guarantees are complemented by Article 27 (5) and (6) providing for legal assistance and interpretation for applicants in the case of appeals. The access to legal assistance free of charge may be restricted by the Member States to cases with "tangible prospects of success" and is limited to the treatment accorded to nationals of the respective state.

The provisions guarantee an effective remedy in law. The question whether the new rules for appeals provide for an effective remedy in practice will very much depend on the interpretation of the CJEU's judgements in the above mentioned cases

\footnotetext{
${ }^{47}$ CJEU, Case C-277/11, M.M., 22 November 2012, ECLI:EU:C:2012:744.

${ }^{48}$ See in particular the judgements of the ECtHR, Application No. 25389/05, Gebremedhin v. France, 26 April 2007 and M.S.S. (above note 44).

${ }^{49}$ Recital 19 of the recast Regulation contains an explanation of this principle: "In order to guarantee effective protection of the rights of the persons concerned, legal safeguards and the right to an effective remedy in respect of decisions regarding transfers to the Member State responsible should be established, in accordance, in particular, with Article 47 of the Charter of Fundamental Rights of the European Union. In order to ensure that international law is respected, an effective remedy against such decisions should cover both the examination of the application of this Regulation and of the legal and factual situation in the Member State to which the applicant is transferred." (emphasis added).
} 
Abdullahi and Puid in the practice of the Member States. Both cases concern the practical effectiveness of an appeal against Dublin decisions.

In Abdullahi the court states that an appeal under the Dublin II Regulation in the context of illegal entry (article 10 of the Dublin II Regulation) is limited to cases of systemic deficiencies. Even though this judgment was clearly limited to the Dublin II Regulation and did not reference the guarantees contained in Article 47 CFR Member States and even courts have interpreted this provision as severely restricting the possibility to even lodge appeals against Dublin decisions. ${ }^{50}$ Other member States and courts have taken a different view. ${ }^{51}$ Also the practice of the ECtHR seems to incorporate the notion of systemic deficiencies. ${ }^{52}$

In Puid the CJEU has reconfirmed its view that the use of the sovereignty clause should be limited to exceptional cases. Nevertheless, most Member States are actually using the sovereignty clause in cases where a transfer is not possible. For the right to appeal it will be decisive whether the courts of the Member States (and/or the CJEU) will take the view that also applicants may base an appeal on the misuse of discretion when assessing the potential application of Article 17. ${ }^{53}$

\subsection{Coercive measures}

The new rules for detention for the purpose of transfer contained in Article 28 have been subject to fierce debates during the recast procedure. The solution that has now emerged as a result of the legislative procedure contains a significant improvement for applicants in number of Member States whereas for other Member States these standards mean a possibility for easier detention for the purpose of Dublin transfers. The standards establish minimum guarantees for applicants and are informed by the standards as contained in international ${ }^{54}$ and in EU law. ${ }^{55}$ Article 28 starts with a reminder of the principle that "Member States shall not hold a person in detention for the sole reason that he or she is subject to the procedure established by this Regulation." It further contains safeguards and rules for detaining persons subject to a Dublin transfer in Article 28 (2) and (3) that are oriented towards the principle of proportionality and provide for an individual assessment and the prior assessment of less coercive measures. Dublin detention is limited to cases where there is a serious

\footnotetext{
${ }^{50}$ Most notably (so far) the German Federal Administrative Court has taken this view: FAC, 10 B 6/14, 19 March 2014.

${ }^{51}$ In the case called EM (Eritrea), [2014] UKSC 12, 19 February 2014, the UK Supreme Court has stated that the real risk test developed by the ECtHR since the case Soering v. UK (Application No. 14038/88, 7 July 1989) remains the valid test.

${ }^{52}$ See e.g. ECtHR, Application No. 71932/12, Mohammadi v. Austria, 3 July 2014, § 74. However, the leading case of Tarakhel v. Switzerland (Application No. 29217/12) is still pending at the time of writing.

${ }^{53}$ See already above under 3.2.2 in the context of the protection of family life.

${ }^{54}$ See $U N H C R$, Guidelines on the Applicable Criteria and Standards relating to the Detention of AsylumSeekers and Alternatives to Detention, 2012.

${ }^{55}$ Most notably in the area of forcible returns as established in particular in Chapter II ("termination of illegal stay") of the Returns Directive (Directive 2008/1 15/EC of the European Parliament and of the Council of 16 December 2008 on common standards and procedures in Member States for returning illegally staying third-country nationals).
} 
risk of absconding and is limited to six weeks (and a total maximum period of detention of three months). If the respective time limits are not complied with (also the shortened time limit for the lodging of a take back or take charge request) the person "shall no longer be detained." Article 28 (3) 1 explicitly refers to a due diligence standard in this regard.

According to Article 28 (4) the guarantees of Articles 9, 10 and 11 of the recast Reception Conditions Directive (RCD) ${ }^{56}$ apply. From a legal point of view these guarantees are for Dublin procedures part of the Regulation and thus immediately binding on all Member States applying the recast Regulation. As the guarantees are part of the Regulation this also applies to "opt-out"-States and associated States. ${ }^{57}$ It is established that the legal effect of references to Directives in Regulations (if the referenced parts are specific enough to be directly applied) means that they have direct effect as part of the Regulation itself. ${ }^{58}$ In practical terms, this means that Article 28 (4) needs to be read as if it would contain the full wording of Articles 9-11 of the recast $\mathrm{RCD}$.

\section{Way forward}

The analysis provided in this article has brought to light that the new rules of the Dublin III Regulation have the potential to enhance effectiveness as well as to ensure higher standards of protection if the respective standards and guarantees are applied in a practical and human rights-sensitive way. The impact of the practical application of the recast Regulation is therefore very much dependent on the national authorities and courts. The tasks for decision makers include the (legal and practical) analysis of the new provisions and their application. It is also necessary to clearly define the challenges and particularly for courts to identify potential precedent setting cases with a view to seeking clarification of ambiguous provisions and/or conflicting norms from the European Institutions (in particular from the CJEU).

Challenges regarding the protection of fundamental rights include the identification and addressing of "grey areas" (i.e. issues left open by the recast Regulation and/or the case law). Most notably issues to be addressed in this context are the notion of the best interests of the child and the protection of the right to family life. More generally, the scope and impact of the newly introduced individual rights, including the procedural rights for applicants, needs to be defined. The most interesting and most disputed area in the past was the right to an effective remedy against a Dublin

\footnotetext{
${ }^{56}$ Directive 2013/33/EU of the European Parliament and of the Council of 26 June 2013 laying down standards for the reception of applicants for international protection (recast).

${ }^{57}$ Ireland, the United Kingdom and Denmark have "opted out" of parts of the CEAS, whereas the "Dublin States" Iceland, Liechtenstein, Norway and Switzerland are not Members of the EU but associated to the Dublin system.

${ }^{58}$ In a case concerning the Common Agricultural Policy the German Federal Administrative Court (FAC) stated that the referenced Directives had direct effect within the scope of application of the Regulation ("Die in Bezug genommenen Richtlinien erlangten im Regelungsbereich der Verordnung unmittelbare Geltung." FAC, 3 C 25.12, 19 September 2013, para 8).
} 
decision. This is likely to continue to be challenging in the future, as the quite restrictive recent case law of the CJEU seems (at least to some extent) to be at variance with the better access to legal remedies for applicants offered by the recast Regulation. As this area has significantly developed over the last years, it is foreseeable that this will remain the core debate in the area of Dublin procedures. The essential question in this regard on the national level is whether there is an obligation to apply Article 17 under specific circumstances and whether an appeal against Dublin decisions beyond the notions of "systemic flaws" is still possible. Only if the answer to both questions is in the affirmative (at least on the national level) a substantial judicial protection of applicants subject to Dublin procedures seems to be possible.

On a practical basis, it can be estimated that the number of appeals will most likely significantly drop, if the aim of a real CEAS is coming closer to reality. As long as diverging standards of protection and reception conditions prevail within the Dublin area and as long as the freedom of movement of beneficiaries of international protection remains restricted, "secondary" movements will remain part of the reality of the CEAS. If the Dublin system shall remain a corner stone of the CEAS, these issues need to be addressed in order to enhance the damaged credibility of the system. ${ }^{59}$

For the future of the CEAS questions of joint processing, a uniform protection status, as well as the rights of beneficiaries of international protection within the CEAS will be decisive for the credibility and effectiveness of the system as a whole and for the responsibility allocation in particular. In this regard, the (unclear) legal situation of the opt-out States and the associated States may become a stumbling block. On the institutional level, it will be a task specifically for coordination mechanisms like the Dublin Contact Committee meetings and for EASO to help to identify and implement practical solutions for the described challenges.

\section{References}

1. Bender, D., Bethke, M.: Dublin III, Eilrechtsschutz und das Comeback der Drittstaatenregelung. Asylmagazin (2013)

2. Maiani, F., Vevstad, V.: Reflection note on the Evaluation of the Dublin system and on the Dublin III proposal, doc. PE 410.690; published within the framework of the ODYSSEUS Research Project "Setting up a Common European Asylum System-report on the application of existing instruments and proposals for the new system" (EP Tender n ${ }^{\circ}$ 2008/S91122789), under the supervision of Philippe De Bruycker (2009)

3. UNHCR: The Dublin II Regulation. A UNHCR discussion paper, April 2006; ECRE, Report on the Application of the Dublin II Regulation in Europe, March 2006; Dublin Transnational Project, The Dublin II Regulation: Lives on hold, February 2013

\footnotetext{
${ }^{59}$ While authorities complain about inconsistent and ineffective procedures especially for transfers, refugee "activists" are concerned about the apparent injustice of the diverging standards of protection and receptions conditions and asylum applicants have significant problems to actually understand the system with the limited information that is available to them (including the fact that they would normally trust the (often flawed) information that they receive within the community and/or from persons that have facilitated their entry rather than the information they receive by authorities and/or lawyers). This leads to a situation where neither the authorities, nor refugee activists, nor asylum applicants actually have faith in the fairness and effectiveness of the Dublin system.
} 
4. UN Committee on the Rights of the Child (CRC): General comment No. 14 (2013) on the right of the child to have his or her best interests taken as a primary consideration (art. 3, para. 1), CRC /C/GC/14, 29 May 2013

5. UN Committee on the Rights of the Child (CRC): General comment No. 6 (2005): Treatment of Unaccompanied and Separated Children Outside their Country of Origin, CRC/GC/2005/6, 1 September 2005 